\title{
Identifikasi Kesalahan Siswa Kelas VII dalam Menyelesaikan Soal Cerita Geometri dengan Newman's Procedure
}

\author{
Fahrur Rozi Hadiyantoํ, Nourma Pramestie Wulandari ${ }^{2}$ \\ ${ }^{1}$ Pendidikan Matematika, FKIP, Universitas Islam Kadiri, Kediri \\ 2 Pendidikan Matematika, FKIP, Universitas Mataram, Mataram
}

e-mail: rozi270609@yahoo.com

\author{
INFORMASI ARTIKEL \\ Keywords : \\ Error Identification; \\ Geometry; Newman's \\ Procedur; Word \\ Problem. \\ Kata Kunci : \\ Identifikasi kesalahan, \\ Geometri, Newman's \\ Procedure; Soal Cerita. \\ Cara Mengutip: \\ Hadiyanto, F. R., \& \\ Wulandari, N. P., \\ (2019). Identifikasi \\ kesalahan siswa kelas \\ VII dalam \\ menyelesaikan soal \\ cerita geometri dengan \\ Newman's procedure. \\ Mandalika \\ Mathematics and \\ Education Journal, \\ 1(2), $81-86$
}

\begin{abstract}
Errors in solving geometry problems can be used as a reference to find out what difficulties are made by students. One of the efforts in helping students who have difficulty in solving geometry problems, is by identifying the results of students' completion of the given problem. The purpose of this study is to identify student errors in solving geometry problems using Newman's Procedure. This study uses a mixed approach (fixed method) using test questions instruments. The subjects of this study were 29 students of class VII C of SMP Negeri 8 Kediri. The results of identification of student answers obtained data that errors in reading problems because students are confused about solving the geometry problems. Comprehension errors of what they read happens because students answer broadly when asked is that many tiles are needed. Transformation errors occur because students incorrectly write numbers while working. Errors in process skill in implementing strategies occur because students choose the wrong strategiy in solving problems. Errors in encoding when students write final answers occur because students do not know that writing down the distance unit while working on problems is not allowed and it's wrong in counting.
\end{abstract}

\section{ABSTRAK}

Kesalahan dalam menyelesaikan soal geometri dapat dijadikan acuan untuk mengetahui kesulitan-kesulitan apa saja yang dilakukan oleh siswa. Salah satu upaya dalam membantu siswa yang kesulitan dalam menyelesaikan soal geometri, yaitu dengan mengidentifikasi hasil penyelesaian siswa terhadap soal yang diberikan. Tujuan dari penelitian ini adalah untuk mengidentifikasi kesalahan siswa dalam menyelesaikan soal geometri dengan menggunakan Newman's Procedure. Penelitian ini menggunakan pendekatan campuran (fixed method) dengan menggunakan instrument soal tes. Subjek penelitian ini ada 29 siswa kelas VII C SMP Negeri 8 Kediri. Hasil identifikasi jawaban siswa diperoleh data bahwa kesalahan dalam membaca soal dikarenakan siswa bingung menyelesaikan soal geometri tersebut. Kesalahan dalam memahami apa yang dibaca terjadi dikarenakan siswa menjawab luas pada saat yang ditanyakan adalah banyak ubin yang dibutuhkan. Kesalahan transformasi terjadi dikarenakan siswa salah menulis angka saat mengerjakan. Kesalahan dalam menerapakan strategi terjadi karena siswa salah memilih strategi dalam menyelesaikan soal. Kesalahan menuliskan jawaban akhir terjadi karena siswa tidak tahu bahwa menuliskan satuan jarak saat mengerjakan soal tidak diperbolehkan dan salah dalam menghitung. 


\section{Pendahuluan}

Matematika sebagai mata pelajaran yang masuk dalam cangkupan kelompok mata pelajaran SMP seperti termuat dalam standar isi struktur kurikulum 2013. Materi yang diajarkan jenjang SMP meliputi bidang kajian bilangan, aljabar, geometri, pengukuran, statistika dan peluang. Materi geometri yang harus dikuasai siswa SMP kelas VII sesuai dengan standar isi yang memuat kompetensi inti dan kompetensi dasar antara lain memahami sifat-sifat bangun datar (segitiga dan segiempat), garis dan sudut, menghitung luas permukaan dan keliling bangun datar (segitiga dan segiempat) [1]

Dalam kompetensi dasar tingkat SMP geometri merupakan salah satu materi yang diajarkan. Hal ini terbukti dengan adanya kompetensi dasar yang berisi tentang memahami sifat-sifat dan rumus luas dan keliling bangun datar segitiga dan segiempat. Selain aritmetika dan aljabar, geometri adalah salah satu cabang yang penting yang mendominasi pembelajaran matematika di high school classes. Aritmetika dan aljabar ilmu tentang bilangan sementara geometri adalah ilmu tentang garis dan bidang [2]. [3]kenapa geometri penting diajarkan yaitu pertama, geometri merupakan cabang matematika yang dapat mengaitkan matematika dengan dunia nyata. Kedua, geometri juga memungkinkan ide-ide matematika yang dapat divisualisasikan. Ketiga, geometri dapat memberikan contoh yang tidak tunggal tentang sistem matematika. Berdasarkan hal tersebut di Indonesia geometri masih merupakan materi yang penting diajarkan.

Pada penelitian ini materinya adalah bangun datar segitiga dan segiempat. Berdasarkan hasil wawancara dengan guru, siswa sering melakukan kesalahan dalam menyelesaikan soal-soal segitiga dan segiempat terutama soal cerita. Misalnya saja, masih banyak siswa yang salah hitung yang dilakukan secara berulang atau siswa salah dalam memahami soal yang diberikan oleh guru. Namun belum ada solusi atau alternatif penyelesaian masalah yang tepat yang sudah dilakukan guru.

Siswa yang melakukan kesalahan dalam menyelesaikan soal segitiga atau segiempat biasanya mengalami kesulitan dalam memahami materi segitiga dan segiempat. Jika kesulitan ini tidak segera diatasi maka akan berdampak pada meteri selanjutnya di jejang yang lebih tinggi. Misalnya, ketika mempelajari bangun ruang sisi datar maka siswa tersebut akan kesulitan dalam memahami materi tersebut, sebab materi tersebut memerlukan segitiga dan segiempat sebagai prasyaratnya. Selain itu dengan tidak memahami materi segitiga dan segiempat mengakibatkan rendahnya prestasi belajar siswa dan berpengaruh terhadap keberhasilan siswa bahkan dimungkinkan menimbulkan sikap ketidaksukaan siswa terhadap mata pelajaran matematika. Salah satu cara untuk mengetahui solusi diawali dengan melalui identifikasi kesulitan belajar dan kesalahan siswa sedini mungkin, maka diharapkan guru dapat memberikan pertolongan dengan cepat sehingga kesulitan dan kesalahan tersebut dapat ditanggulangi dan diatasi.

Pengertian identifikasi menurut [4] identifikasi adalah penentuan jenis masalah atau kelainan atau ketidakmampuan dengan meneliti latar belakang penyebabnya atau dengan cara menganalisis gejala-gejala yang tampak. Kesalahan merupakan penyimpangan terhadap hal yang benar. Kesalahan dalam metematika [5] adalah penyimpangan dari solusi yang tepat dari suatu masalah, baik secara konsep maupun prosedur penyelesaiannya. Selain itu [6] kesalahan terjadi ketika siswa tahu apa yang harus dilakukan berikutnya, tetapi mereka salah dalam langkahnya, misalnya saat subtitusi nilai atau keliru perhitungan. [7] mengatakan bahwa jawaban yang tidak sesuai dengan kriteria (yang diharapkan) disebut jawaban salah. Dalam penelitian ini siswa dikatakan melakukan kesalahan dalam menyelesaikan soal geometri ketika siswa melakukan penyimpangan terhadap solusi yang tepat dari suatu masalah. Identifikasi kesalahan yang dimaksudkan dalam penelitian ini adalah mencari semua jenis kesalahan yang dilakukan siswa dalam menyelesaikan soal cerita geometri dengan menggunakan Newman's Procedure.

Newman (1977b,1983) dalam [8] menyatakan bahwa ada lima tipe kesalahan yang dilakukan siswa dalam menyelesaikan soal cerita, yaitu a) kesalahan dalam membaca soal/masalah, b) kesalahan dalam memahami apa yang dibaca, c) kesalahan dalam melaksanakan transformasi dari kata-kata yang ada dalam pertanyaan untuk memilih 
strategi apa yang tepat, d) kesalahan dalam menerapkan keterampilan proses yang dituntut oleh strategi yang dipilih, dan e) kesalahan menuliskan jawaban akhir. Banyak penelitian menjelaskan bahwa masih banyak kesalahan yang dilakukan siswa dalam menyelesaikan soal cerita geometri. Selain itu terdapat beberapa penelitian yang menggunakan Newman's procedure untuk menganalisis kesalahan siswa dalam menyelesaikan soal cerita antara lain a) Clements \& Ellerton (1996), b) Junaedi, Iwan (2012), c) Prakitipong \& Nakamura (2006), dan d) Singh, dkk. (2010). Hal tersebut juga dibenarkan oleh salah seorang guru yang mengatakan bahwa sebagian besar siswa masih melakukan kesalahan dalam menyelesaikan soal cerita geometri.

Untuk mengatasi kesalahan-kesalahan siswa dalam menyelesaikan soal geometri, maka upaya yang perlu dilakukan adalah mengidentifikasi kesalahan-kesalahan tersebut. Adapun yang diidentifikasi adalah jenis kesalahan yang dilakukan oleh siswa dalam menyelesaikan soal cerita geometri. Dengan diketahui jenis kesalahan yang dilakukan siswa maka dapat ditentukan alternatif penyelesaian agar siswa tersebut tidak melakukan kesalahan dalam menyelesaikan soal cerita geometri. Sedangkan materi geometri yang dimaksudkan adalah segitiga dan segiempat kelas VII. Kompetensi dasar yang dipilih adalah kompetensi dasar menyelesaikan permasalahan nyata yang terkait penerapan sifat-sifat persegi panjang, persegi, trapesium, jajargenjang, belah ketupat, dan layang-layang.

\section{Metode}

Dalam penelitian ini digunakan pendekatan campuran (fixed method). Pendekatan kuantitatif digunakan untuk menentukan banyaknya kesalahan yang siswa lakukan. Hal ini dilakukan dengan cara mengoreksi jawaban tes siswa berkaitan dengan segitiga dan segiempat. Pendekatan kualitatif digunakan untuk mendeskripsikan jenis kesalahan yang dilakukan siswa. Hal ini dilakukan dengan cara mengidentifikasi jawaban tes siswa. Dari jenis kesalahan yang dilakukan oleh siswa selanjutnya akan disusun langkah-langkah agar kesalahan tersebut tidak terulang kembali.

Adapun prosedur pelaksanaan dalam penelitian ini dapat dilihat pada Gambar 1 . Dalam Gambar 1 dapat dilihat bahwa penelitian ini dimulai dengan memilih kelas VII C di SMP Negeri 8 Kediri untuk kelas penelitian. Kelas VII C dipilih karena kelas tersebut merupakan kelas yang heterogen dibandingkan kelas yang lainnya. Selanjutnya siswa diminta mengerjakan soal tes berupa soal cerita yang berhubungan dengan geometri (segitiga dan segiempat). Kemudian jawaban semua siswa di identifikasi letak kesalahan yang dilakukan berdasarkan Newman's Procedure. Setelah melakukan identifikasi jawaban siswa ada dua hal yang dilakukan yakni menetukan alternatif penyelesaian dan pendeskripsian jenis kesalahan siswa dalam menyelesaikan soal geometri (segitiga dan segiempat). Hasil pendeskripsian jenis kesalahan siswa inilah yang nantinya akan ditulis dalam laporan penelitian.

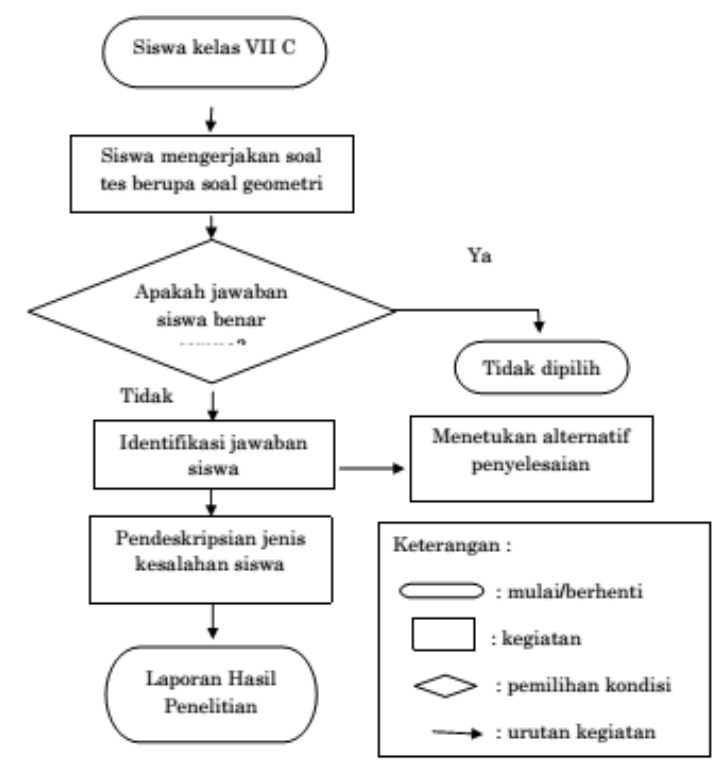

Gambar 1 Diagram Alur Prosedur Pelaksanaan Penelitian 


\section{Hasil dan Pembahasan}

Berikut ini adalah soal yang diberikan pada waktu penelitian.

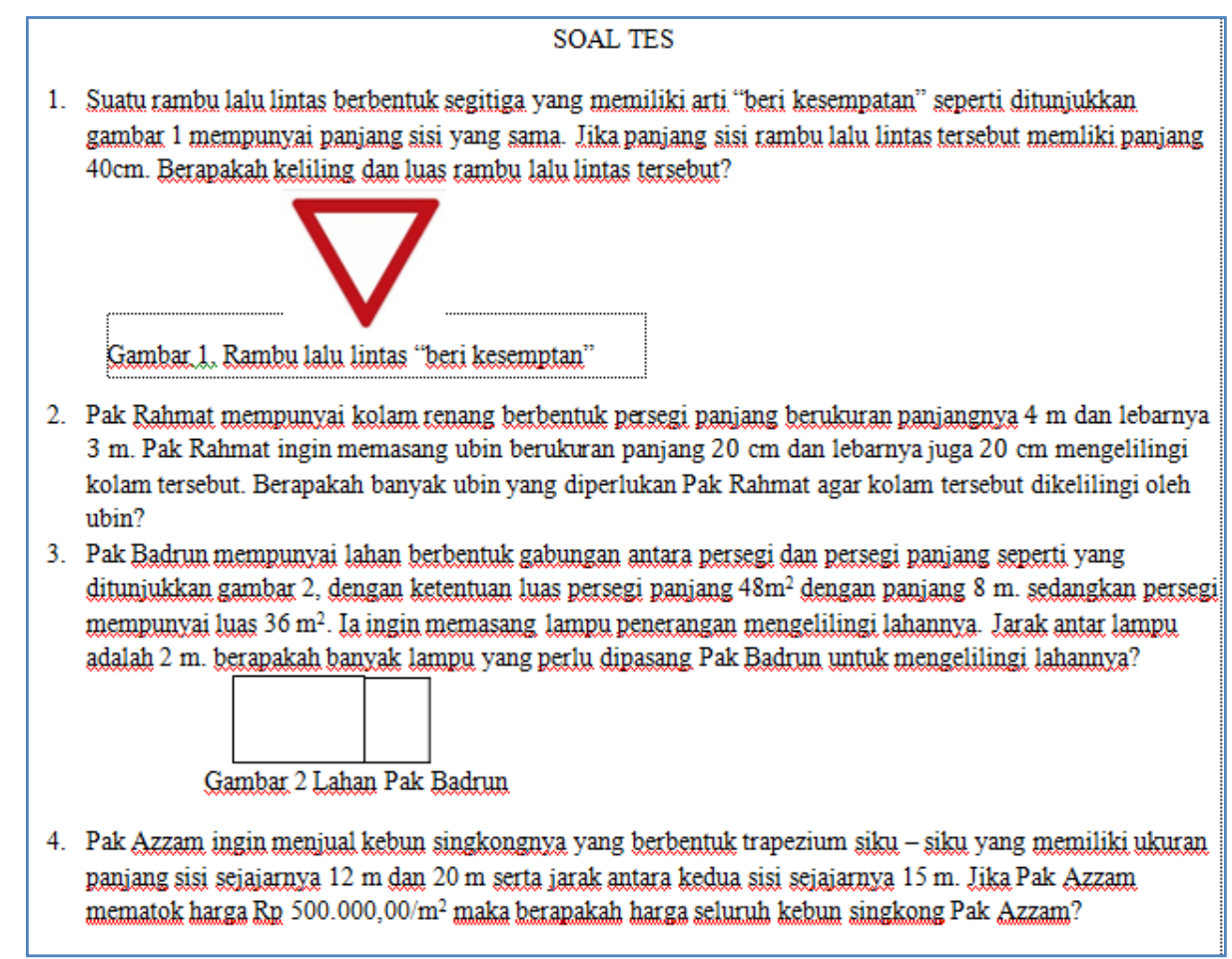

Gambar 2. Soal Tes Siswa

Berdasarkan hasil analisis jawaban tes yang telah dilakukan ditemukan kesalahan yang dilakukan siswa dalam menyelesaikan soal geometri sebagai berikut:

1. Untuk soal nomor satu diperoleh data sebagai berikut:

a. Siswa yang melakukan kesalahan membaca soal ada $0 \%$

b. Siswa yang melakukan kesalahan memahami apa yang dibaca ada $0 \%$

c. Siswa yang melakukan kesalahan transformasi ada $7 \%$

d. Siswa yang melakukan kesalahan menerapkan strategi ada $0 \%$

e. Siswa yang melakukan kesalahan menuliskan jawaban akhir ada $93 \%$

2. Untuk soal nomor dua diperoleh data sebagai berikut:

a. Siswa yang melakukan kesalahan membaca soal ada $14 \%$

b. Siswa yang melakukan kesalahan memahami apa yang dibaca ada $17 \%$

c. Siswa yang melakukan kesalahan transformasi ada $24 \%$

d. Siswa yang melakukan kesalahan menerapkan strategi ada $21 \%$

e. Siswa yang melakukan kesalahan menuliskan jawaban akhir ada $24 \%$

3. Untuk soal nomor tiga diperoleh data sebagai berikut:

a. Siswa yang melakukan kesalahan membaca soal ada $48 \%$

b. Siswa yang melakukan kesalahan memahami apa yang dibaca ada $7 \%$

c. Siswa yang melakukan kesalahan transformasi ada $17 \%$

d. Siswa yang melakukan kesalahan menerapkan strategi ada $17 \%$

e. Siswa yang melakukan kesalahan menuliskan jawaban akhir ada $11 \%$

4. Untuk soal nomor empat diperoleh data sebagai berikut:

a. Siswa yang melakukan kesalahan membaca soal ada $69 \%$

b. Siswa yang melakukan kesalahan memahami apa yang dibaca ada $0 \%$

c. Siswa yang melakukan kesalahan transformasi ada $4 \%$

d. Siswa yang melakukan kesalahan menerapkan strategi ada $4 \%$

e. Siswa yang melakukan kesalahan menuliskan jawaban akhir ada 7\%

Berdasarkan data identifikasi jawaban siswa di atas ada beberapa hal yang menjadi masalah dari siswa yaitu pada soal nomer 1 kesalahan yang paing banyak dilakukan oleh siswa adalah mereka salah menuliskan satuan jarak kedalam perhitungan. Soal nomer 2 kesalahan yang mereka lakukan adalah siswa lupa menghitung ubin yang ditaruh dipojokkan kolam. Soal nomer 3 siswa bingung cara mengerjakannya karena sudah menggunakan gabungan dua bangun datar. Soal nomer 4 siswa juga tidak bisa mengerjakan karena bingung menentukan tingginya yang mana. Selain kesalahan mayoritas tadi, siswa juga melakukan kesalahan kesalahan lain antara lain: kesalahan dalam perhitungan, kesalahan dalam menentukan satuan luas dan keliling, kesalahan 
yang hanya menghitung luas tanpa menghitung banyak lampu yang diperlukan, kesalahan dalam menghitung keliling ubin, dll.

Untuk mengurangi kesalahan yang dilakukan oleh siswa peneliti mengemukakan alternatif penyelesaian agar hal tersebut tidak terulang lagi. Alternatif penyelesaian yang dikemukakan yakni menganalisis penyebabnya dan scaffolding. Dengan menganalisis penyebab terjadinya kesalahan tersebut dengan cara mewawancarai siswa tersebut. Setelah mengetahui penyebab terjadinya kesalahan itu nanti bisa ditentukan bentuk scaffolding yang cocok untuk mengurangi kesalahan yang dilakukan oleh siswa. Hal ini didukung oleh penelitian yang telah dilakukan oleh Ramadhani (2015)[9], Noviyanti [10](2014) dan Pratama[11] (2014) pada materi aljabar yang menunjukkan bahwa scaffolding dapat mengurangi atau menyadarkan siswa akan kesalahan yang dilakukan dalam menyelesaikan soal aljabar.

Scaffolding diperkenalkan oleh Wood, dkk. (1976). Wood, dkk.[12] menyatakan scaffolding sebagai suatu proses dimana seorang siswa dibantu menuntaskan masalah tertentu melampui kapasitas perkembangannya melalui bantuan dari seorang guru atau orang lain yang lebih kompeter dan secara perlahan-lahan bantuan tersebut akan ditinggalkan ketika siswa tersebut telah dapat menyelesaikan masalah sendiri. Scaffolding bersifat fleksibel artinya bantuan tersebut dapat diberikan sewaktu-waktu dan dapat dihentikan ketika siswa telah mampu menyelesaikan masalahnya (Amipour dkk.,2012 \& Westwood, 2004)[14].

\section{Penutup}

Berdasarkan hasil identifikasi jawaban di atas dapat ditarik kesimpulan dari penelitian ini adalah sebagai berikut:

1. Jenis kesalahan dari siswa dalam menyelesaikan soal cerita yang berkaitan dengan segitiga dan segiempat adalah sebagai berikut:

a. Siswa yang melakukan kesalahan membaca soal antara lain salah dalam menentukan tinggi trapezium.

b. Siswa yang melakukan kesalahan memahami apa yang dibaca, kurang memahami cara mencari banyak ubin sehingga siswa ada yang mengitung keliling ubinnya juga.

c. Siswa yang melakukan kesalahan transformasi, yaitu salah dalam menuliskan kembali apa yang diketahui. Contohnya yang seharusnya ditulis $12+20=32$ menjadi $12+20=22$.

d. Siswa yang melakukan kesalahan menerapkan strategi, seharusnya mencari keliling ada yang mencari luas.

e. Siswa yang melakukan kesalahan menuliskan jawaban akhir, kesalahan dalam operasi penjumlahan dan salah dalam menuliskan satuan jarak kedalam perhitungan

2. Kesalahan terbanyak yang dilakukan oleh siswa adalah kesalahan dalam menuliskan jawaban akhir pada soal nomer 1 yakni sebesar 93\%. Sedangkan kesalahan paling sedikit yang dilakukan oleh siswa adalah kesalahan dalam membaca soal pada nomer 1, kesalahan dalam memahami apa yang dibaca pada nomer 1, kesalahan menerapkan strategi pada nomer 1, dan kesalaha dalam memahami apa yang dibaca pada nomer 4 yang kesemuannya memiliki presentase yang sama yakni sebesar $0 \%$.

Adapun saran dalam penelitian ini adalah sehubungan dengan hasil penelitian yang telah dilakukan adalah sebagai berikut:

1. Alternatif penelitian yang dikemukakan peneliti yakni dengan melakukan analisis penyebab terjadinya kesalahan tersebut serta menggunakan scaffolding.

2. Scaffolding dipilih karena dengan scaffolding bisa mengurangi kesalahan yang dilakukan oleh siswa. Selain itu scaffolding bersifat fleksibel artinya bantuan tersebut dapat diberikan sewaktu-waktu dan dapat dihentikan ketika siswa telah mampu menyelesaikan masalahnya.

3. Karena kesalahan terbanyak yang dilakukan oleh siswa adalah kesalahan dalam menuliskan satuan jarak pada saat perhitungan maka sebaiknya guru memberi tahu bahwa hal tersebut tidak diperbolehkan. 
Diharapkan agar alternatif penyelesaian yang telah dikemukakan oleh peneliti bisa diujicobakan sebagai tindak lanjut penelitian ini dan sekaligus sebagai upaya dalam penyempurnaan.

\section{Referensi}

[1]. Kementrian Pendidikan dan Kebudayaan. (2011). Salinan Lampiran Permendikbud No. 68 Tahun 2013 Tentang Kurikulum SMP-MTs.Jakarta: Departemen Pendidikan dan Kebudayaan

[2]. Saini, M. (2015). A Diagnostic Study of Errors Commited by $8^{\text {th }}$ Grade Students of Government School in Solving Problems of Geometry. International Journal in Management and Social Science. Vol.3 issue 7

[3]. Usiskin, Z. (1982). Van Hiele Levels and Achievement in Secondary School Geometry.(Final Report of The Cognitive Development and Achievement in Secondary School Geometry Project). Chicago: University of Chicago

[4]. Sugihartono, dkk. (2006). Psikologi Pendidikan. Yogyakarta : Universitas Negeri Yogyakarta

[5]. Young, R dan O'Shea, T.(1981). Errors in Children's Subtraction. Cognitive Science, 5(2): 152-177.

[6]. Sandhu, D. (2013). Does anyone have any information on the differences between misconceptions and errors in mathematics. Research Gate., (Online), (http://www.researchgate.net/post/Does_anyone_have_any_information_on_the differences_between_misconceptions_and_errors_in_mathematics), diakses 6 Maret 2016

[7]. Mirza, A. (1998). Analisis Kesalahan Belajar Matematika. Pontianak : FKIP UNTAN.

[8]. Clements \& Ellerton. (1996). The Newman Procedure for Analysis Errors on Written Mathematical Task. The University of Newcastle: Faculty of Education

[9]. Ramadhani, A.N. (2015). Analisis Kesalahan Siswa Kelas VII pada Materi Aljabar serta Proses Scaffolding-Nya. Tesis tidak diterbitkan. Malang: Pascasarjana UM.

[10]. Noviyanti, M. (2014). Diagnosis Kesalahan Siswa dalam Menyelesaikan Soal Aljabar serta Upaya Scaffolding Guru. Tesis tidak diterbitkan. Malang: Pascasarjana UM.

[11]. Pratama, S. (2014). Kesalahan Siswa Kelas VIII SMP dalam Aljabar dan Upaya Mengatasinya Menggunakan Scaffolding. Tesis tidak diterbitkan. Malang: Pascasarjana UM.

[12]. Anghileri, J. (2006). Scaffolding Pactices that Enhance Mathematics Learning. Journal of Mathematics Teacher Education, Vol.9, halaman 33-52

[13]. Amiripour, P.,dkk. (2012). Scaffolding as Effective Method for Mathematics Learning. Indian Journal of Science and Technology. Vol.5, No.9

[14]. Westwood, P. (2004). Learning and Learning Difficulties :A Handbook for Teachers. Australian Council for Educational Research: Acer Press 